\title{
Economics
}

2019; 8(4): 128-133

http://www.sciencepublishinggroup.com/j/eco

doi: 10.11648/j.eco.20190804.11

ISSN: 2376-659X (Print); ISSN: 2376-6603 (Online)

\section{A Study on Life Insurance Fund Investment in Transportation Infrastructure}

\author{
Zhai Yigang \\ School of Public Finance and Tax, Central University of Finance and Economics, Beijing, China
}

Email address:

150010098@qq.com

\section{To cite this article:}

Zhai Yigang. A Study on Life Insurance Fund Investment in Transportation Infrastructure. European Journal of Biophysics.

Vol. 8, No. 4, 2019, pp. 128-133. doi: 10.11648/j.eco.20190804.11

Received: September 6, 2019; Accepted: October 14, 2019; Published: October 23, 2019

\begin{abstract}
Transportation infrastructure projects are often large in scale, and they require lots of long-term and concentrated funds, which is different from investments like stocks. With long-term saving function, life insurance funds own lots of stable long-term funds, whose nature matches the characteristics of infrastructure project gains, and can invest in large-scale transportation infrastructure and serve as a source of funds for long-term and stable investment in transportation infrastructure. It is necessary to fully understand the significance of life insurance fund investment in transportation infrastructure, and explore and study the similarities between life insurance fund and transportation infrastructure fund. This paper analyzes the significance of life insurance funds investing in transportation infrastructure construction, and argues that the role of life insurance funds investing in transportation infrastructure should be valued from the perspectives of macro environment, preservation and appreciation, regulatory system and cross-industry competition. By studying the characteristics of life insurance funds and the practice of life insurance funds investing in transportation infrastructure, the conclusion is that life insurance funds should invest more in transportation infrastructure construction. The main ways are to increase the asset allocation of transportation infrastructure, select the investment mode scientifically and establish the risk control system pertinently.
\end{abstract}

Keywords: Life Insurance Funds, Transportation Infrastructure, Investment Model, Risk Control System

\section{Introduction}

In recent years, China continued to invest more in transportation infrastructure construction. Transportation infrastructure projects are often large in scale, and they require lots of long-term and concentrated funds, which is different from investments like stocks. This requires a certain level of initial investment to make sure the whole process of construction is fully and timely funded and project construction goes well. [3] Transportation infrastructure will maintain a high level in the middle and long term in the future, and it has attracted insurance funds, especially life insurance funds, with its great fund demand and long cycle. With long-term saving function, life insurance funds have lots of stable and long-term funds, whose nature matches the characteristics of infrastructure project gains, and can invest in large-scale transportation infrastructure and become a source of funds for long-term and stable investment in transportation infrastructure.

Life insurance fund investment in transportation infrastructure is of significance. Life insurance funds refer to capital funds, public accumulation funds, undistributed profits, reserves and other funds priced by domestic or foreign currencies of insurance group (holding) companies and insurance companies who run life insurance business. In terms of the size of capital: as of the end of 2018, the balance of insurance funds used was 16.408838 trillion yuan, up 9.97\% than the beginning of the year. In light of investment structure: as of the end of 2018, deposits in banks totaled 2.43635 trillion yuan, accounting for $14.85 \%$; bonds totaled 5.638297 trillion yuan, taking up $34.36 \%$; stocks and securities investment funds totaled 1.921987 trillion yuan, accounting for $11.71 \%$; other investments totaled 6.412204 trillion yuan, taking up $39.08 \%{ }^{1}$. Among them, funds of life insurance companies took up over $80 \%$ of the total of the industry. Insurance funds continue to exploit their advantages, innovate methods, open up channels and increase the quality and efficiency of serving

${ }^{1}$ Statistical data from the China Banking and Insurance Regulatory Commission Jan, 2019 
the real economy, which is of significance to transportation infrastructure projects. From the perspective of life insurance funds, the changes in several aspects require life insurance funds to pay more attention to transportation infrastructure projects:

At first, new normal macro environment puts considerable pressure for life insurance funds to preserve or increase the value. In terms of the economic cycle, the world economy grows at a low speed as a whole and economic recovery is weak. Influenced by low economic growth and loose monetary policy, low interest rate or negative interest rate has become normal in the world economy. For a long time to come gross domestic product (GDP) will slow down and economic growth will show L-shaped trend. Departments at all levels and the public have formed consistent expectations. The Chinese consumer market is expected to exceed 40 trillion yuan by $2020 .{ }^{2}$ Compared with price inflation and hiking asset price, interest rates in the constant return market are too low, the room for the maintenance of value and appreciation offered by the financial market is not very large at present.

Second, a continued increase in the size of capital puts considerable pressure to value preservation and appreciation. Since the State Council approved the resumption of domestic business in 1979, the insurance market have experienced great changes, insurance companies are increasingly diversified, premium income increases rapidly, types of insurance continue to increase, and an enormous amount of money is amassed. [4] Revenue from insurance premium increased from 139.321 billion yuan in 1999 to $3,801.662$ billion yuan in 2018; total assets increased from 260.409 billion yuan in 1999 to 18.330892 trillion yuan in 2018 ; the amount of investment increased from 89.141 billion yuan in 1999 to 16.408838 trillion yuan in $2018 .{ }^{3}$ Compared with general social capital, life insurance funds naturally match some major construction projects and people's livelihood projects that have a huge demand for funds and a long investment period. Ever-growing business scale requires life insurance funds to make use of their unique advantages, namely long term and "conversion period", and seize the important strategic opportunity in the national supply-side structural reform and wealth management. [5]

Third, changes in the regulatory system and the supervision system put high pressure for life insurance fund to maintain its value or appreciate. After China enacted Insurance Law in the Sixteenth National Congress of the Communist Party of China in 1995, by taking a series of measures, including the China Insurance Regulatory Commission (CIRC) specially established the Fund Management Regulatory Department in 2003 and implementing the new Insurance Law of 2009, channels for the use of insurance funds are gradually

\footnotetext{
${ }^{2}$ The Boston Consulting Group (BCG) Supply-Side Reform Benchmark Studies on Different Reform Pathway 2016

${ }^{3}$ Statistical data from the China Banking and Insurance Regulatory Commission January 2019 Statistical data from the China Insurance Regulatory Commission January 2000
}

expanded, prompting the use of insurance fund to come to take the path of professionalism and marketization. In recent years, the CIRC offered market players more investment options by stabilizing the scope and integrating and simplifying regulations, and market and innovation incentive were significantly boosted. Investments in fields like infrastructure investment, equity investment are gradually increased, basically achieving a diversified allocation of insurance funds. The establishment of the CIRC condensed the room for regulatory arbitrage by related institutions, and it will continue to strengthen its regulation over the use of insurance funds. Solvency II regulatory system provides the use of insurance funds with room, but also raises higher requirements for risk management and the ability to invest. The Solvency II detailed quantitative capital requirements for insurance risk, market risk and credit risk, and increased qualitative risk requirements for operational risk and liquidity risk. Its influence on the use of insurance funds is mainly manifested in three aspects: meticulous and comprehensive depiction of asset risks, increased proportion of alternative investment and increasingly important investment tactics.

Fourth, cross-industry competition puts great pressure for life insurance funds to preserve or appreciate their value. Life insurance funds always face the cross-industry competition with other institutions due to product homogeneity. As the integrative development of the insurance industry and assets management industries including banking, securities, fund and trust constantly deepens, sub-industries of the assets management market, such as bank financial product and trust, have become important external factors that influence China's use of insurance funds. Changes in the return of bank financial products have a significant influence on China's size of insurance funds. Taking the banking industry as an example, bank financial products bear a striking resemblance to universal insurance, the main investment-oriented insurance product in the life insurance market now, in target customer, nature of capital, marketing channel and other aspects, so they are like products in the market. Moreover, there is a significant correlation between trust and the return on insurance wealth management product in China. The development of the insurance industry and the assets management market are important external and internal factors that influence China's use of insurance funds.

\section{Life Insurance Funds Naturally Match the Fund Demand of Transportation Infrastructure}

In light of the fund demand of transportation infrastructure, lots of long-term financing gaps need long-term and stable funds, while life insurance funds naturally match it. At present, traditional long-term funds are highly limited and hard to meet the demand of lots of transportation infrastructures and the field of public service in the future. Different insurance investments vary in their demand for safety, liquidity, profitability and risk tolerance because their sources are 
different. In particular, life insurance funds own lots of long-term funds since they have long-term saving function, and its nature matches the characteristics of infrastructure project gains, so it can be used for investing in large infrastructure projects. Long-term and interest margin are the unique advantages of infrastructure assets. Transportation infrastructure construction is characterized by large scale, relatively stable return and so on, consistent with the characteristics and investment objectives of insurance funds and naturally compatible with insurance fund. Life insurance funds can be a long-term and stable source of investment fund for infrastructure, especially transportation infrastructure, and its role and meaning are increasingly prominent.

The characteristics of transportation infrastructure accord with the needs of life insurance funds. As a large-scale project, transportation infrastructure has the following characteristics: first, long investment cycle and slow investment recovery. The duration of a long-term collaborative project is around 25 to 35 years or even longer, and only after a certain operating cycle can it achieve the recovery of project investment. Second, high initial investment and stable return. Infrastructure construction constantly increases demand, and its initial investment must reach a certain level, to make sure the whole construction process is fully and timely funded and the construction goes well. Third, resist inflation and achieve the appreciation of assets. Normally, an inflation adjustment mechanism will be established for premiums. From the perspective of long-term investment objectives, investing in transportation infrastructure can resist inflation risk indeed, and it is an effective investment channel to maintain the value of assets. Fourth, less affected by the economic cycle. General business decisions match the economic cycle. When the economy grows fast, production and operation will be expanded, while production as well as production and operational costs will be reduced in case of economic depression. Nonetheless, transportation infrastructure construction is different from general business operations in some ways that infrastructure is indispensable regardless of economic situation. In case of economic depression or tight fiscal policy, to stabilize the economy, we should energetically build infrastructures, which are less affected by the economic cycle.

Although how domestic and foreign scholars represent the principles of the use of life insurance funds are different in details, their thoughts reflected are basically consistent. In general, they all stress three principles, namely safety, return and liquidity. Since transportation infrastructure construction has a stable cash flow and more flexible systematic risk, it deviates from the fluctuations of other asset prices to some degree. Reasonable investment can help life insurance funds effectively prevent risks and preserve or increase their value. On the whole, transportation infrastructure construction has something in common. First, the consistency of principles. Life insurance funds pay attention to safety, fluidity and profitability (appreciation) in terms of investment principle. Meanwhile, transportation infrastructure construction has corresponding requirements in these three aspects, and safety should be put first for the investment of life insurance funds. Second, compatibility of goals. Life insurance products gradually become a basic risk management and wealth management method for governments, companies and residents, a major channel to improve the level of assurance and ensure the quality, and an effective tool for the government to enhance public service and strengthen social management. Third, they need and promote each other. Life insurance funds need to achieve diversification in the form of investment and may increase investment in transportation infrastructure. The supply of life insurance funds is highly consistent with the fund demand of transportation infrastructure. Both are policy-oriented, long-term, safe and large-scale. Policy means both are policy-oriented. Long-term means life insurance fund investment requires a large sum of money and a long and stable investment period, while the financing of transportation infrastructure also needs a large amount of capital and its investment recovery takes a longer time.

\section{Life Insurance Investment in Infrastructure Construction Is Experienced in Practice}

From the perspective of transportation infrastructure, financing activities conducted by foreign transportation infrastructure constructions are mostly for expressways or national arterial highways. [6] Although each of their expressway financing models has their own characteristics, these models can be roughly divided into the following three types according to the source of fund: central financial system, special fund system and project financing. Besides these three common investment and financing models, project financingand concession contract-based road concession system are widely adopted in the field of road construction in foreign countries. Besides developed countries, some developing countries also successfully raised funds for the construction of expressways by adopting concession, such as the North-South Expressway in Malaysia and Bangkok Phase II Expressway in Thailand. Since the concession system of project financing has clear financiers, for directly using transferee' funds or issuing corporate bonds and raising stocks and funds, the financing costs can be paid back with project gains, which makes financing more flexible and increases fund utilization rate and is a helpful supplement to traditional investment and financing systems for roads of different countries. [7]

Foreign life insurance funds invest in the construction of transportation infrastructure in two ways, namely direct investment and indirect investment. Direct investment is about setting up a private equity fund to establish and operate an infrastructure project, while indirect investment packs assets into securitized products for sale or set up a trust fund to manage clients' funds. Return on investment in infrastructure project is only lower than other forms of investment. [8] In light of international experience, life insurance fund investing in toll roads through the capital market and other real estates 
and toll roads financing through the capital market is universal. Foreign countries already do not simply take investing in infrastructure or other real estates as a way to spread risk, rather, they increasingly treat it as a major means to gain return on investment. Insurance companies in the United States, Japan, Germany, South Korea, Singapore and other countries have a certain proportion of real estate investment to total assets. However, the possession of real estates or direct investment in it are equity investment, but this kind of asset is considered as unfit for life insurance companies due to the uncertainty of its cash flow, the proportion of this kind of asset to the portfolios of insurance companies in developed countries is not high.

In light of domestic experience, according to statistical data provided by the China Public Private Partnerships Center, PPP projects and related industries are currently concentrated. [9, 10] As of 2018, transportation always tops the list in terms of the number of projects, total amount of investment, number of projects launched and other aspects. Therefore, in principle, life insurance funds should choose the optimal transportation infrastructure construction project to invest in from the abovementioned industries. [11]

\section{Conclusion}

Life insurance fund usually has the characteristics of fund safety, large quantity, long term and low cost. Transportation infrastructure projects usually have the characteristics of long cycle, high investment security and stable income, compared to other investment projects. The investment of life insurance funds in transportation infrastructure projects can effectively disperse the investment risks of capital market insurance institutions and provide appropriate sources of funds for the projects. [11, 12] Transportation infrastructure projects can provide stable cash flow for insurance institutions during future operations. Life insurance capital investment in transportation infrastructure has three advantages. First, there is plenty of money. At present, the construction of transportation infrastructure in China mainly involves the infrastructure of national economy and people's livelihood, such as railway, high-speed and other aspects. A key feature of such projects is that they require large amounts of money. [13] At the same time, insurance funds have the characteristics of large scale and sufficient funds. Second, the investment term is long. The investment construction and payback period of transportation infrastructure projects are generally more than ten years. In the early stages of construction, it is necessary to invest a lot of money. Bank financing institutions can have limited medium - and long-term loan funds. However, in terms of insurance funds, the long investment period is one of its biggest advantages. [14, 15] The life insurance and pension insurance have a relatively long term. Life insurance fund investment can be extended to 10-30 years, both match perfectly. Third, risk appetite is low. Transportation infrastructure project reduces the overall risk of the project through reasonable risk allocation principle, and the government expenditure responsibility has been included in the fiscal budget, so the payment risk is less. A common low-risk appetite allows life insurance funding to match perfectly with transport infrastructure projects.

Life insurance capital investment in transportation infrastructure has a good basis for cooperation and development prospects. [16] In terms of cooperation basis, the characteristics of life insurance funds are highly compatible with the key points of financing needs of transportation infrastructure. The investment and operation principles of life insurance funds are similar to the characteristics of transportation infrastructure projects. There is a certain degree of homology between the investment preference of funds and the attributes of projects. [17] The cooperation between life insurance fund and transportation infrastructure is highly feasible. We should appropriately increase the life insurance investment in transportation infrastructure, draw lessons from domestic and foreign experience, and increase the life insurance investment in transportation infrastructure projects.

\section{Policy Suggestions}

\subsection{Increase Assets Allocated to Transportation Infrastructure}

During "the 12th Five-Year Plan" period, various modes of transportation grew rapidly in China, integrated transportation system was constantly improved, planned targets and missions were well completed, and the requirements of socioeconomic development were meet on the whole. Transportation infrastructure has invested 13.4 trillion yuan in total, 1.6 times higher than that during "the 11th Five-Year Plan" period, and it ranked first in the world in terms of high speed railway operating mileage, expressway traffic mileage, urban rail transit operating mileage, and the average number of berths in coastal port at million tons level and above. Meanwhile, the development of natural gas pipeline network accelerated, and a network of transportation infrastructure took shape. The "13th Five-Year Plan" for Modern Integrated Transportation System issued by the State Council proposed to basically set up a safe, convenient, efficient and green modern integrated transportation system and let some regions and fields be the first to basically realize the modernization of transportation by 2020. Besides, it is necessary to establish and perfect central-local investment linkage mechanism, and optimize the way of arranging government investments. Based on the pilots, we should accelerate the application and popularity of public-private partnership (PPP) model in the field of transportation and encourage the involvement in the construction, operation and maintenance of transportation projects through concession, government purchasing services and other means. [18] Then, more financial support should be given to policy-oriented and development finance institutions on the premise of controllable risk, the scale of direct financing should be expanded, and we should support insurance funds to join the construction of major transportation infrastructures in various ways, including creditor's rights and stock rights. $[19,20]$ Hebei Province is an 
important logistics center and passenger transfer station in China. Plan for Coordinated Development of the Integrated Transportation in Beijing-Tianjin-Hebei Region (2014-2020) proposed that the Beijing-Tianjin-Hebei region will focus on creating a regional axis for urban and rural development based on the existing channels and patterns, promote interconnectivity between cities, and advance the transformation from a radial channel pattern with one center to the gridded pattern of "four ordinates, four horizontal axes and one ring".

\subsection{Choose Investment Model in a Scientific Way}

Insurance fund investment in infrastructure construction may choose debt investment model or equity investment model. [21] The specific form of debt investment model is bond-type trust plan, equity investment model includes direct equity investment, industrial investment fund and asset securitization, etc. [22] An insurance company may select a corresponding investment model according to project characteristics. Equity investment is demanding for insurance companies, as it needs related professionals who are familiar with the field of infrastructure, but its return is normally higher than that of debt investment model. For example, some projects that have the potential to get listed may choose equity investment in order to obtain high return when listed. The duration of an equity investment project is generally longer than that of a debt investment project, so if the future direction of a project is uncertain or it is not easy to exit, one may choose debt investment and gain principal and interest when due.

\subsection{Establish a Targeted Risk Control System}

The characteristics of life insurance fund naturally match it naturally with transportation infrastructure, but it is necessary to design a corresponding system for its risks and pay attention to the following aspects since transportation infrastructure is relatively complicated. [23] First, we should pay attention to government credit and fiscal capacity. The ability to fulfill and economic strength of local government become important factors that determine the success of operation, so when we chooses a local government for cooperation, we should pay close attention to its credit history, financial capacity, GDP and growth rate, general public budgets, revenues and expenses, and meanwhile ask local governments to list fiscal expenditure of the cooperative project among in the financial budget and medium- and long-term financial plan of that year. [24] Besides, we should pay attention to credit and strength of industrial funder. Since life insurance funds pursue safe profit, and transportation infrastructure contains some risks, we should choose a suitable industrial funder as the partner, then its scale, qualification, performance, market, strength, credit rating and partnership with local government are the key indicators that an insurance company must measure. [25] Next, we should pay attention to compliance and economic evaluation of the project itself, thoroughly study various normative documents, choose those transportation infrastructure projects that meet procedural requirements, and avoid the situation where the launch and advancement of the project is affected by compliance-induced controversy. Before investing in a project, life insurance funds need to intervene into consultation and negotiation with the industrial funder at the earlier stage of the project, conduct a thorough feasibility study, set up a complete financial analysis model, estimate economic indicators and decide whether they can guarantee investment and meet investment demand.

\section{References}

[1] Wu rongzhen, insurance funds applied to expressway problem research, [D]. chang 'an university doctoral thesis, 2009.

[2] Liu kexin, Analysis of insurance fund investment in infrastructure construction strategy, [J]. time finance, 2016.

[3] Yan bing; Feasibility study of insurance funds participating in PPP projects of infrastructure construction, [J]. modern commercial industry, 2017.

[4] Notice of the State Council on printing and distributing the development plan of the 13th five-year plan for the modern comprehensive transportation system.

[5] Shen yuzheng, PPP model analysis of Canadian pension fund investment infrastructure and its enlightenment to China, [D]. Master's thesis of southwestern university of finance and economics, 2013.

[6] Dai shiqing, highway project investment and financing research, [D]. doctoral thesis of central south university, 2011.

[7] Cui Liyuan; Yao Mengyang; How to develop the modern comprehensive transportation system during the 13th five-year plan period, [J]. Transportation construction and management, 2017.

[8] 2009 China highway industry research report.

[9] Yao weijie; Chen Bangxian, how much money do you have, [J]. Highway in China, 2012.

[10] Wang Boyu; Zheng Quan; Chapter governing, a comparative analysis of the management system of expressway assets at home and abroad, [C]. academic papers on expressway management in China (volume 2010), 2010.

[11] Mou xiangyu, management system of traffic fee collection based on J 2 EE, [D]. master thesis of chongqing university, 2009.

[12] Huang sheng, research and implementation of traffic fee system based on service-oriented architecture, [D]. master thesis of Hunan university, 2007.

[13] Wang hui, new changes in the application of insurance capital from the perspective of insurance market and big capital management, $[\mathrm{J}]$. contemporary financier, 2017.

[14] Xang zhaohui, discussion on the mode of financing and financing of China's, [J]. road construction with loans and loan repayment with fees, 2009.

[15] Zhao ruihua, research on the source and use of funds for rural road construction and maintenance in chuansha xinzhen, [D]. master's thesis of Fudan university, 2011. 
[16] Yao dafeng, inspiration to China from the development and evolution of Korean life insurance products, [D]. doctoral thesis of graduate school of Chinese Academy of Social Sciences, 2019.

[17] Han zhaozhu Dong zhen, research on the integration of Beijing-Tianjin-Hebei transportation based on holistic governance, $\mathrm{j}[\mathrm{J}]$. ournal of hebei university (philosophy and social sciences edition)", 2019.

[18] A shwin, M. PPP Experiences in Indian cities: Barriers, enablers, and the way forward [J]. Journal of Constructing Engineering and Management, 2010.

[19] Becker S, Deuber G, Stankiewicz S, et al. Public debt in 2020 [J]. Deutsche Bank Research, 2010 (6): 50. [9] Hochrainer S, Timonina A, Williges $\mathrm{K}$, et al. Modelling the economic and fiscal risks from natural disasters [J]. Insights based on the CatSim model Background Report for GAR, 2013.

[20] Casper van Ewijk, Paul JG Tang. Improving the assessment of economic foreign exchange exposure in public-private partnership infrastructure projects [J]. Journal of infrastructure systems, 2012.

[21] Chan A. P. C, Lam P. T. I, Chan D. W. M, etal. Potential obstacles to successful implementation of Public-Private Partnership sin Beijing and the Hong Kong special administrative region $[\mathrm{J}]$. Journal of Management in Engineering, 2010 (1).

[22] DohJP, Ramamurti R. Reassessing Riskin Developing Country Infrastructure [J]. Long Range Planning, 2003, 36 (4).

[23] Grimsey D, Lewis MK. Evaluating the risks of public private partnerships for infrastructure projects [J]. International Journal of Project Management, 2002, 20 (2): 107-118.

[24] Guasch J L. Granting and Renegotiating Infrastructure Concessions: Doing it Right [J]. World Bank Publications, 2004.

[25] Iossa E, MartimortD. Corruptionin PPPs, Incentives and Contract In completeness [J]. International Journal of Industrial Organization, 2016. 